University of Nebraska - Lincoln

DigitalCommons@University of Nebraska - Lincoln

1985

\title{
The Nutritional Value of Normal and High Lysine Corns for Weanling and Growing-Finishing Swine When Fed at Four Lysine Levels
}

G. L. Asche

University of Nebraska-Lincoln

A. J. Lewis

University of Nebraska-Lincoln, alewis2@unl.edu

E. R. Peo, Jr.

University of Nebraska-Lincoln

J. D. Crenshaw

University of Nebraska-LincolnUniversity of Nebraska-Lincoln

Follow this and additional works at: https://digitalcommons.unl.edu/animalscifacpub

Part of the Animal Sciences Commons

Asche, G. L.; Lewis, A. J.; Peo, Jr., E. R.; and Crenshaw, J. D., "The Nutritional Value of Normal and High Lysine Corns for Weanling and Growing-Finishing Swine When Fed at Four Lysine Levels" (1985). Faculty Papers and Publications in Animal Science. 675.

https://digitalcommons.unl.edu/animalscifacpub/675

This Article is brought to you for free and open access by the Animal Science Department at DigitalCommons@University of Nebraska - Lincoln. It has been accepted for inclusion in Faculty Papers and Publications in Animal Science by an authorized administrator of DigitalCommons@University of Nebraska - Lincoln. 


\title{
THE NUTRITIONAL VALUE OF NORMAL AND HIGH LYSINE CORNS FOR WEANLING AND GROWING-FINISHING SWINE WHEN FED AT FOUR LYSINE LEVELS ${ }^{1,2,3}$
}

\author{
G. L. Asche, A. J. Lewis ${ }^{4}$, E. R. Peo, Jr. and J. D. Crenshaw \\ University of Nebraska ${ }^{5}$, \\ Lincoln 68583-0908
}

\begin{abstract}
Summary
One-hundred-ninety-two weanling pigs from two separate trials, (initial weight 6.0 and 5.6 $\mathrm{kg}$ ) and 400 growing-finishing pigs (initial weight $17 \mathrm{~kg}$ ) were fed normal and high lysine corn diets containing four levels of lysine in a 2 $\times 4$ factorial arrangement. Crossbred (Large White $\times$ Landrace $\times$ Duroc) pigs were used in all experiments. The objectives of the experiments were to (1) compare normal and high lysine corn when fed at different lysine levels, (2) determine the lysine requirements for the three stages of growth and (3) evaluate the effect of protein level on the lysine requirement. All diets were balanced on a lysine basis. The results indicated that both weanling and growingfinishing pig performance and final carcass composition were similar for pigs fed normal or high lysine corn diets balanced on a lysine basis. Weanling pigs from 5 to $14 \mathrm{~kg}$ required at least $1.10 \%$ lysine. Based on changes in body weight gain and feed efficiency, the lysine requirement of growing pigs (17 to $54 \mathrm{~kg}$ ) was $.70 \%$, and that of finishing pigs ( 54 to $101 \mathrm{~kg}$ ) was $.50 \%$. However, based on lean tissue growth rate (as reflected by longissimus muscle area and percentage of lean in the carcass) the requirement was at least $.75 \%$ during the growing stage
\end{abstract}

\footnotetext{
${ }^{1}$ Published as Paper No. 7637, Journal Series, Nebraska Agr. Exp. Sta. Research reported was conducted under Project 13-052.

${ }^{2}$ The technical assistance of Mary B. Barnes and Roy. L. Carlson, and the contributions of Dr. A. D. Flowerday in growing the corns used in Exp. 2 are gratefully acknowledged.

${ }^{3}$ Supported in part by a grant from Crow's Hybrid Corn Co., Milford, IL 60953.

${ }^{4}$ To whom reprint requests should be addressed.

${ }^{5}$ Dept. of Anim. Sci.

Received November 26, 1984.

Accepted January 30, 1985.
}

and $.60 \%$ during the finishing stage. The reduced protein level ( $2 \%$ lower) of the high lysine corn diets did not reduce the lysine required by pigs compared with those fed normal corn.

(Key Words: Swine, High Lysine Corn, Protein, Lysine, Requirement.)

\section{Introduction}

Since the incorporation of the opaque-2 gene into corn hybrids (Mertz et al., 1964; Nelson et al., 1965; Nelson, 1966), numerous authors have reported that high lysine corn containing the opaque-2 gene is nutritionally superior to normal corn. These results have been observed with both weanling pigs (Drews et al., 1969; Wahlstrom et al., 1977) and growing and finishing pigs (Pickett, 1966; Cromwell et al., 1967; Gallo et al., 1968; Cromwell et al., 1969; Jensen et al., 1969; Sihombing et al., 1969; Gilster and Wahlstrom, 1970; Pick and Meade, 1970; Gipp and Cline, 1972; Marroquin et al., 1973; Veum et al., 1973).

Yields of high lysine corn have commonly been lower than their normal hybrid counterparts (Brown, 1975). Recently, however, improvements in yield have spurred renewed interest in high lysine corn usage. Information on both the nutritional value of the higheryielding varieties and the performance of swine fed high lysine corn at various dietary lysine levels is limited.

There are data that suggest that decreases in dietary protein may reduce the lysine requirement of swine when all other amino acids are adequate (Klay, 1964a,b; Baker et al., 1975; Lunchick et al., 1978; Easter and Baker, 1980). These data were obtained in experiments using diets containing crystalline lysine, and may therefore be confounded by differences in availability of lysine from different sources. 
The objectives of the present research were to (1) compare the performance of weanling and growing-finishing pigs fed diets composed of normal and high lysine corn containing four different lysine levels, (2) determine lysine requirements for the weanling (6 to $14 \mathrm{~kg}$ ), growing (17 to $54 \mathrm{~kg}$ ) and finishing (54 to 101 $\mathrm{kg}$ ) stages and (3) evaluate the effect of different protein levels, between normal and high lysine corn diets, on the lysine requirement.

\section{Experimental Procedure}

Exp. 1. A total of 192 crossbred pigs, averaging 3 wk of age, were allotted in two separate trials ( $A$ and $B$ ) on the basis of sex and weight outcome groups to eight dietary treatments. The treatments were arranged factorially; two corn types (normal and high lysine) and four lysine levels $(.80, .95,1.10$ and $1.25 \%)$. Treatments 1 through 4 were composed of normal corn and soybean meal and treatments 5 through 8 were composed of high lysine corn and soybean meal. The normal corn was purchased commercially from a local source. The high lysine corn was from different sources in each trial and was grown during the 1982 season. All diets were balanced according to the analyzed lysine content of the dietary ingredients (corns and soybean meal) with no protein restriction; consequently the diets were not isonitrogenous. The compositions of the diets fed in trial $A$ are presented in table 1; diets fed in trial B were similar. The diets were calculated to meet NRC (1979) requirements for all nutrients other than protein and lysine.

Weanling pigs (average initial weights were 6.0 and $5.6 \mathrm{~kg}$ for trials $\mathrm{A}$ and $\mathrm{B}$, respectively) were housed in an environmentally controlled nursery with continuous artificial light, and were fed a complex starter diet containing $20 \%$ protein for $2 \mathrm{~d}$ before the start of the experiment. There were four pigs/pen (two barrows and two gilts) and three pens/treatment. Pigs were allowed ad libitum access to feed and water during the 28-d experiments. Feed intakes and pig weights were recorded weekly.

Diets and diet ingredients were analyzed for crude protein, $\mathrm{Ca}$ and $\mathrm{P}$ (AOAC, 1980) and amino acids. Amino acid analysis was by ion

\footnotetext{
${ }^{6}$ Dionex, Sunnyvale, CA.

${ }^{3}$ Technicon ion exchange resin (C4), Technicon Corp., Tarrytown, NY.
}

exchange chromatography using an amino acid analyzer $^{6}$, with a cation exchange resin ${ }^{7}$ and o-phthalaldehyde as the derivatization reagent (Benson and Hare, 1975). Tryptophan analysis was by the autoanalyzer procedure of Lewis et al. (1976) after alkaline hydrolysis.

Dietary ingredients were analyzed before formulation of the diets. The composition of the ingredients is shown in table 2 , and the protein and lysine contents of the diets are presented in table 3 . The analyzed lysine contents of the diets were lower than expected in some diets. In particular, in trial A the lysine analyses of some of the high lysine corn diets (treatments 5 to 8 ) were lower than anticipated from the analysis of the ingredients (high lysine corn and soybean meal). The experimental design was based on the analyses of the ingredients, and therefore results are discussed on that basis. However, because of the differences in diet analyses between trials, the data from the two trials were not combined.

Blood samples were collected at the end of both trials between 1300 and $1400 \mathrm{~h}$ by vena cava puncture using 20 -gauge needles. Samples were collected in 10-ml evacuated, bloodcollection tubes containing sodium heparin. Plasma was separated by centrifugation at $1,116 \times \mathrm{g}$ for $15 \mathrm{~min}$ at $0 \mathrm{C}$. Individual samples were analyzed for plasma urea using the autoanalyzer procedure described by Marsh et al. (1965). One milliliter of plasma from each pig was pooled to make a group sample for each pen. The pooled plasma samples were deproteinized for lysine analysis using a $15 \%$ solution of sulfosalicylic acid added to the plasma as described by Mondino et al. (1972). The protein precipitate was separated by centrifugation at $1,116 \times \mathrm{g}$ for $10 \mathrm{~min}$ at $0 \mathrm{C}$. All samples were frozen until analyzed. Plasma lysine concentrations were determined using the same ion exchange chromatography procedure described for the analysis of diets and diet ingredients. All analyses were performed on duplicate samples.

Exp. 2. Four hundred crossbred (Large White $\times$ Landrace $\times$ Duroc) barrows and gilts (initial wt $17 \mathrm{~kg}$ ) were allotted on the basis of sex and weight outcome groups to eight dietary treatments with five pens/treatment and 10 pigs/pen. Dietary arrangement was similar to Exp. 1, with treatments 1 through 4 being composed of normal corn and soybean meal and treatments 5 through 8 being composed of high lysine corn and soybean meal. The normal 


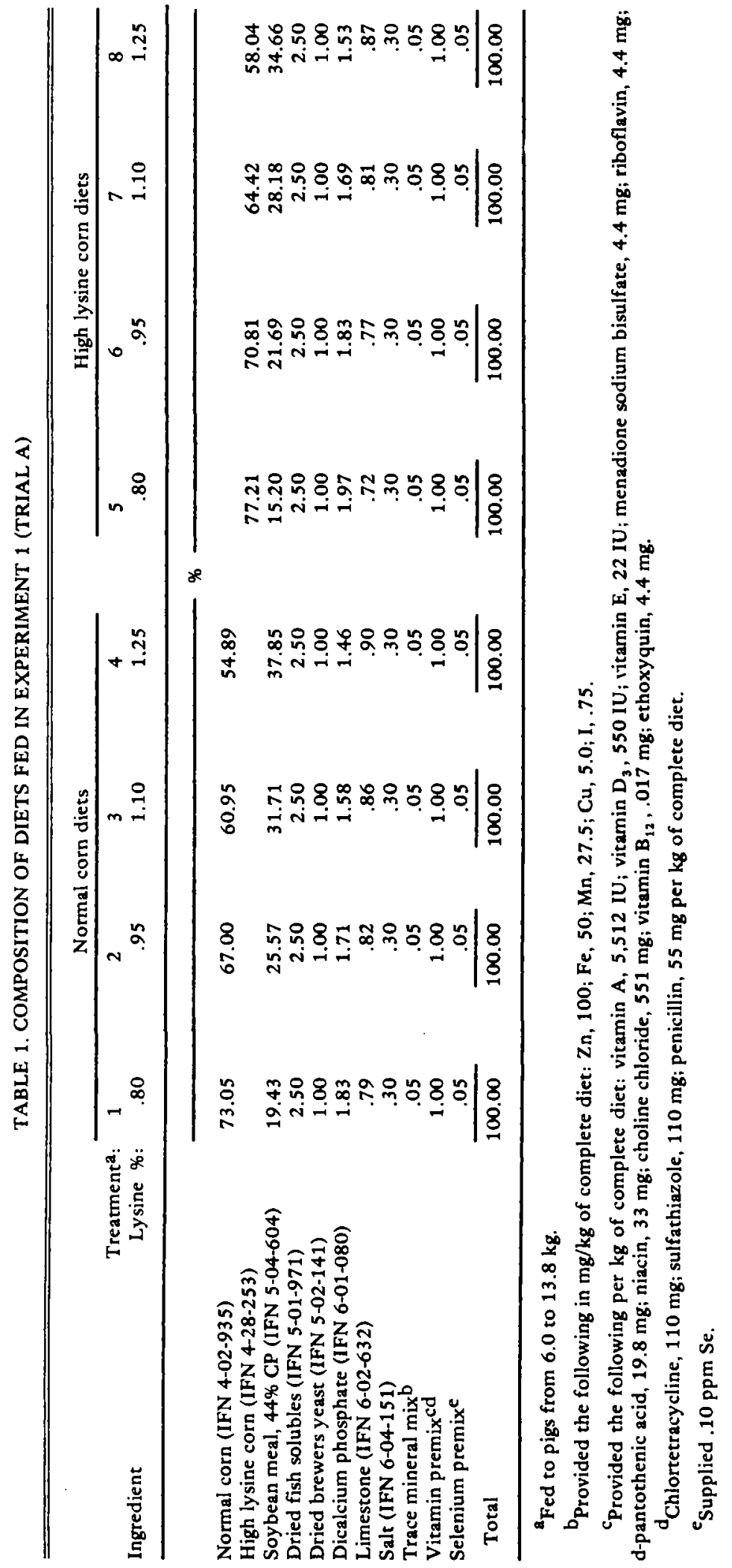


TABLE 2. ANALYZED DRY MATTER, PROTEIN, CALCIUM, PHOSPHORUS AND AMINO ACID COMPOSITION OF NORMAL AND HIGH LYSINE CORNS AND SOYBEAN MEAL

\begin{tabular}{|c|c|c|c|c|c|c|}
\hline \multirow{2}{*}{$\begin{array}{l}\text { Item } \\
\text { Dry matter }\end{array}$} & \multicolumn{2}{|c|}{ Normal corns } & \multicolumn{3}{|c|}{ High lysine corns } & \multirow{2}{*}{ 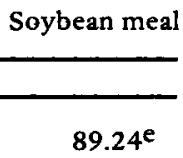 } \\
\hline & $86.60^{\mathrm{a}}$ & $85.96^{b}$ & $83.56^{c}$ & $87.50^{d}$ & $85.72^{b}$ & \\
\hline Protein & 7.83 & 8.31 & 6.66 & 8.06 & 7.68 & 43.67 \\
\hline Calcium & .02 & .02 & .02 & .02 & .03 & .23 \\
\hline Phosphorus & .25 & .25 & .23 & .24 & .24 & .63 \\
\hline \multicolumn{7}{|l|}{ Amino acids } \\
\hline Arginine & .46 & .37 & .38 & .45 & .46 & 3.27 \\
\hline Histidine & .27 & .22 & .22 & .25 & .24 & 1.13 \\
\hline Isoleucine & .32 & .30 & .19 & .23 & .25 & 2.02 \\
\hline Leucine & 1.23 & 1.20 & .58 & .79 & .70 & 3.49 \\
\hline Lysine & .28 & .23 & .28 & .33 & .33 & 2.87 \\
\hline Methionine & .17 & .12 & .09 & .09 & .11 & .48 \\
\hline Phenylalanine & .47 & .43 & .26 & .33 & .30 & 2.22 \\
\hline Threonine & .33 & .31 & .26 & .29 & .29 & 1.85 \\
\hline Tryptophan & .09 & .09 & .09 & .09 & .10 & .77 \\
\hline Valine & .36 & .33 & .30 & .35 & .37 & 1.97 \\
\hline Alanine & .73 & .67 & .45 & .54 & .49 & 1.97 \\
\hline Aspartic acid & .63 & .55 & .58 & .59 & .66 & 5.50 \\
\hline Glutamic acid & 1.85 & 1.81 & 1.15 & 1.37 & 1.38 & 9.02 \\
\hline Glycine & .36 & .33 & .31 & .35 & .37 & 1.91 \\
\hline Serine & .44 & .43 & .30 & .34 & .34 & 2.30 \\
\hline Tyrosine & .32 & .25 & & & .21 & 1.61 \\
\hline
\end{tabular}

\footnotetext{
${ }^{a}$ Experiment 1 (weanling pigs).

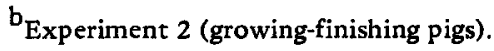

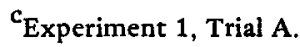

$\mathrm{d}_{\text {Experiment 1, Trial B. }}$.

$\mathrm{e}_{\text {Mean of three sources of soybean meal. }}$
}

and high lysine corn varieties (Crow's $688^{8}$ and SL- $75^{8}$, respectively) were grown during the 1981 season by the Department of Agronomy at the University of Nebraska-Lincoln on both irrigated and nonirrigated land. Yield checks before harvest resulted in similar yields for both corn types without irrigation and slightly lower yields for high lysine corn compared with normal corn with irrigation. Both corn types were processed using a roller mill to minimize dust and keep particle size similar. Samples of diet ingredients and diets were analyzed by the same methods described for Exp. 1. The protein and lysine contents of the diets are given in table 4.

Pigs were housed in modified-open-front finishing buildings and were allowed ad libitum

\footnotetext{
${ }^{8}$ Supplied by Crow's Hybrid Corn Co., Milford, IL 60953.
}

access to feed and water. The pigs were weighed and feed consumption recorded biweekly. A change from grower to finisher diets was made when the average weight of the pigs was $54 \mathrm{~kg}$. Each replication was terminated when the average pig weight within the replication was approximately $100 \mathrm{~kg}$.

Upon termination, pigs were shipped to a commercial slaughterhouse. Carcass data were collected from pigs in the first three replications of the experiment (24 pens). Pigs that weighed $90 \mathrm{~kg}$ or less were not used for the carcass data. Backfat measurements were made perpendicular to the chine opposite the first rib, last rib and last lumbar vertebra. The mean of these measurements was adjusted to a constant hot carcass weight. Length was measured from the anterior edge of the first rib to the anterior edge of the aitch bone. Loins were separated from the rest of the carcass and split between the 10 th and 11 th ribs to determine the size of 


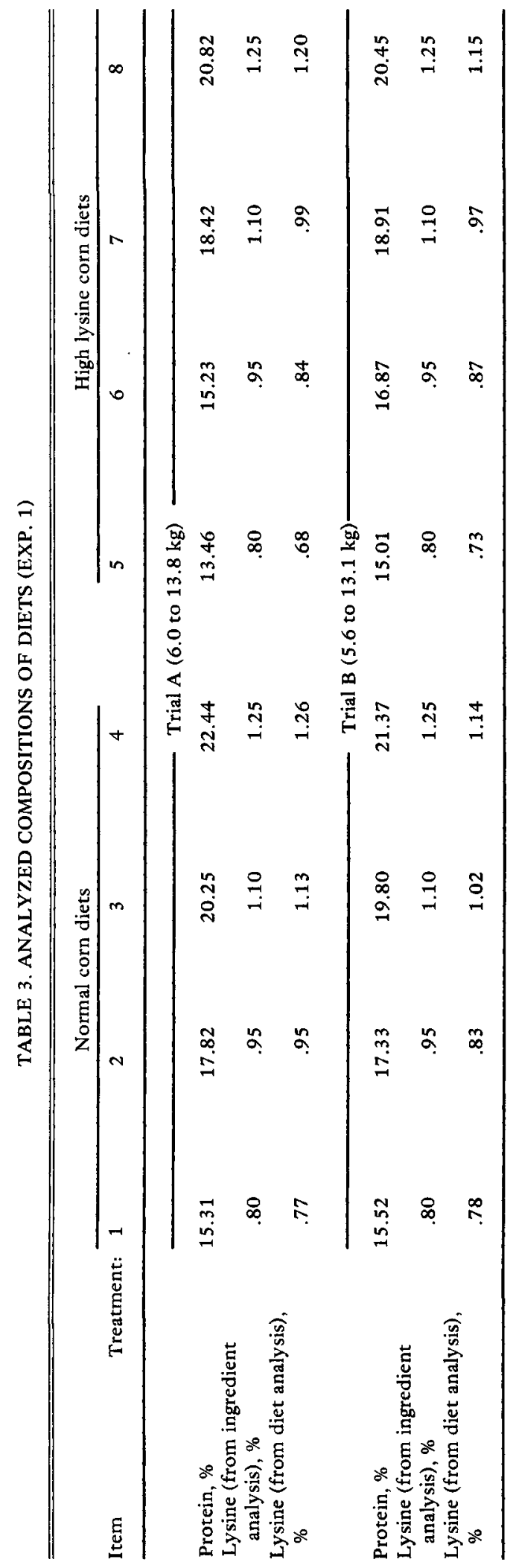

the longissimus muscle. Area was determined by a compensating polar planimeter and was adjusted to a constant hot carcass weight. Both adjustments, adjusted longissimus muscle area (ALMA) and adjusted average backfat (AABF) were made by using average hot carcass weight as a covariable (details of the adjustment methods are provided in footnotes to table 11). Percentage of lean was calculated using the following equation (Fahey et al., 1977):

Percentage lean $=$

$\{[(.41 \times$ hot carcass wt $)-(9.36 \times \mathrm{AABF})+(5.93 \times$ ALMA $)]-5.37\} / 90$ hot carcass wt

Statistical Methods. Data from both experiments were analyzed by analysis of variance procedures for a randomized complete-block design and a factorial arrangement of treatments, and calculated by the Statistical Analysis System (SAS, 1979). The main effect of lysine level was divided into single-degree-of-freedom orthogonal regression contrasts (Steel and Torrie, 1980).

\section{Results}

Exp. 1. The performance data for trials A and $B$ are presented in tables 5 and 6 , respectively. Plasma urea and lysine concentrations for both trials are presented in table 7 .

In trial $A$, average daily gain (ADG) increased and feed/gain $(F / G)$ decreased with increasing levels of dietary lysine (linear, $\mathrm{P}<.001$; quadratic, $\mathrm{P}<.01)$. In addition, average daily feed intake (ADFI) also increased in response to increased lysine (linear, $\mathrm{P}<.05$; quadratic, $\mathrm{P}<.10$ ). The main effect of corn type was not significant for any of the criteria. Pigs fed high lysine corn gained more weight and were more efficient at $1.25 \%$ lysine than pigs fed normal corn. The reverse was true at $.80 \%$ lysine. This difference in performance between corn types caused a corn type $x$ lysine level linear interaction for ADG $(\mathrm{P}<.10)$ and $F / G(P<.05)$.

Results of trial $B$ indicate that ADG, ADFI and $F / G$ all increased (significant linear and quadratic effects) as lysine level increased. In agreement with trial $\mathrm{A}$, there were no significant main effects for corn type. There was a corn type $X$ lysine level linear interaction $(P<.01)$ for $F / G$.

Plasma urea concentrations of pigs in trial A increased linearly $(\mathrm{P}<.001)$ and quadratically $(\mathrm{P}<.05)$ with increases in dietary lysine. In 


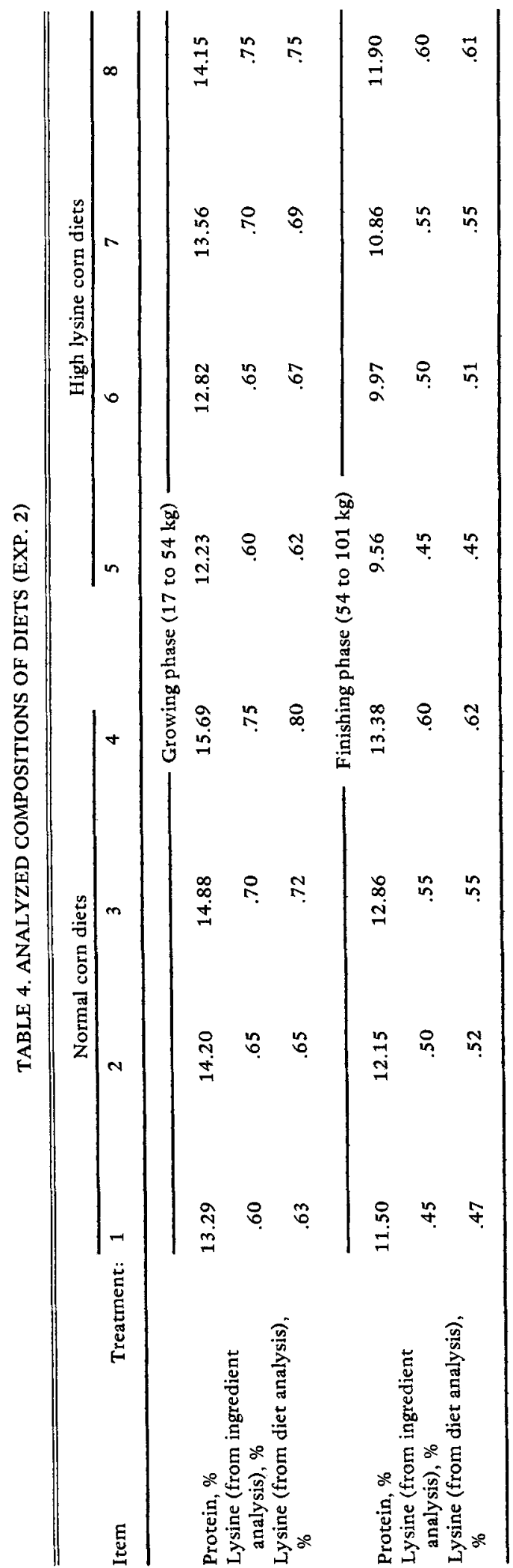

addition, urea concentrations were somewhat higher $(\mathrm{P}<.10)$ in pigs fed normal corn than those fed high lysine corn diets. In trial B, plasma urea concentrations also increased in response to lysine level $(\mathrm{P}<.05)$, but there were no differences $(\mathrm{P}>.70)$ due to corn type.

Plasma lysine concentrations of pigs in trial $\mathrm{A}$ increased linearly $(\mathrm{P}<.001)$ and cubically $(\mathrm{P}<.05)$ as dietary lysine increased. Plasma lysine was higher for pigs fed high lysine corn $(\mathrm{P}<.05)$, and there was a corn type $x$ lysine level interaction $(\mathrm{P}<.10)$. In trial $B$ plasma lysine concentrations also increased linearly $(\mathrm{P}<.001)$ as dietary lysine increased. There was a tendency for plasma lysine concentrations to be higher in pigs fed high lysine corn than in pigs fed normal corn $(\mathrm{P}>.39$ ).

Exp. 2. Performance results are divided into growing, finishing and overall phases and are presented in tables 8,9 and 10 , respectively. Consistently throughout the experiment there were no differences between corn types when averaged over all lysine levels for ADG, ADFI and $F / G$.

Results of the growing phase indicate that ADG and $F / G$ improved $(P<.001)$ as dietary lysine level increased. The main effect of lysine was not significant for ADFI. There was evidence of corn type $\times$ lysine level interactions for each of the three criteria $(P<.05$ to $P<.10)$. The average effect of lysine level for all criteria showed that performance was improved with each increment of lysine.

In the finishing phase there was less response to dietary lysine level. Nevertheless, increasing lysine levels resulted in improvements in ADG (linear, $\mathrm{P}<.05$ ) and $\mathrm{F} / \mathrm{G}$ (quadratic, $\mathrm{P}<.10$ ). There were trends $(P<.10)$ indicating corn type $x$ lysine level interactions for ADG and ADFI.

When growing and finishing phases were combined, increasing the lysine level improved ADG (linear, $\mathrm{P}<.001$ ) and $\mathrm{F} / \mathrm{G}$ (linear, $\mathrm{P}<.001$; quadratic, $\mathrm{P}<.01)$, but did not affect $(\mathrm{P}>.13)$ ADFI. The interactions between corn type and lysine level noted in both individual phases also appeared as quadratic interactions for ADG.

Carcass composition data from 220 pigs are presented in table 11. A sex effect was evident for all criteria. Gilts had lighter weight carcasses $(74.5$ vs $78.4 \mathrm{~kg})$, less adjusted backfat ( $3.55 \mathrm{vs}$ $3.97 \mathrm{~cm})$, larger ALMA (35.1 vs $32.0 \mathrm{~cm}^{2}$ ) and higher percentage of lean $(54.8$ vs $51.7 \%)$ than barrows $(\mathrm{P}<.001)$ and slightly longer $(81.9$ vs $80.4 \mathrm{~cm}$ ) carcasses $(P<.10)$. Increasing the dietary lysine level significantly increased hot 
ASCHE ET AL.

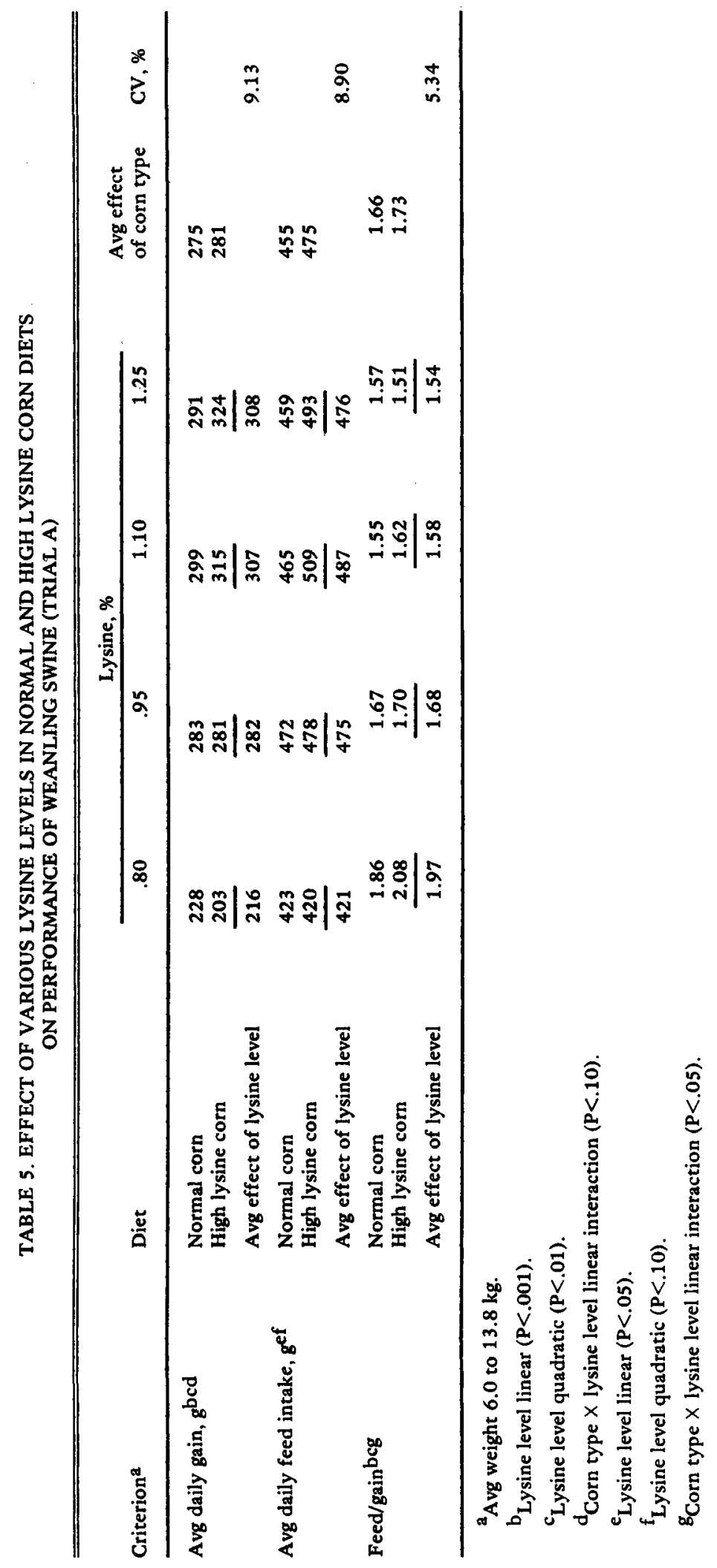




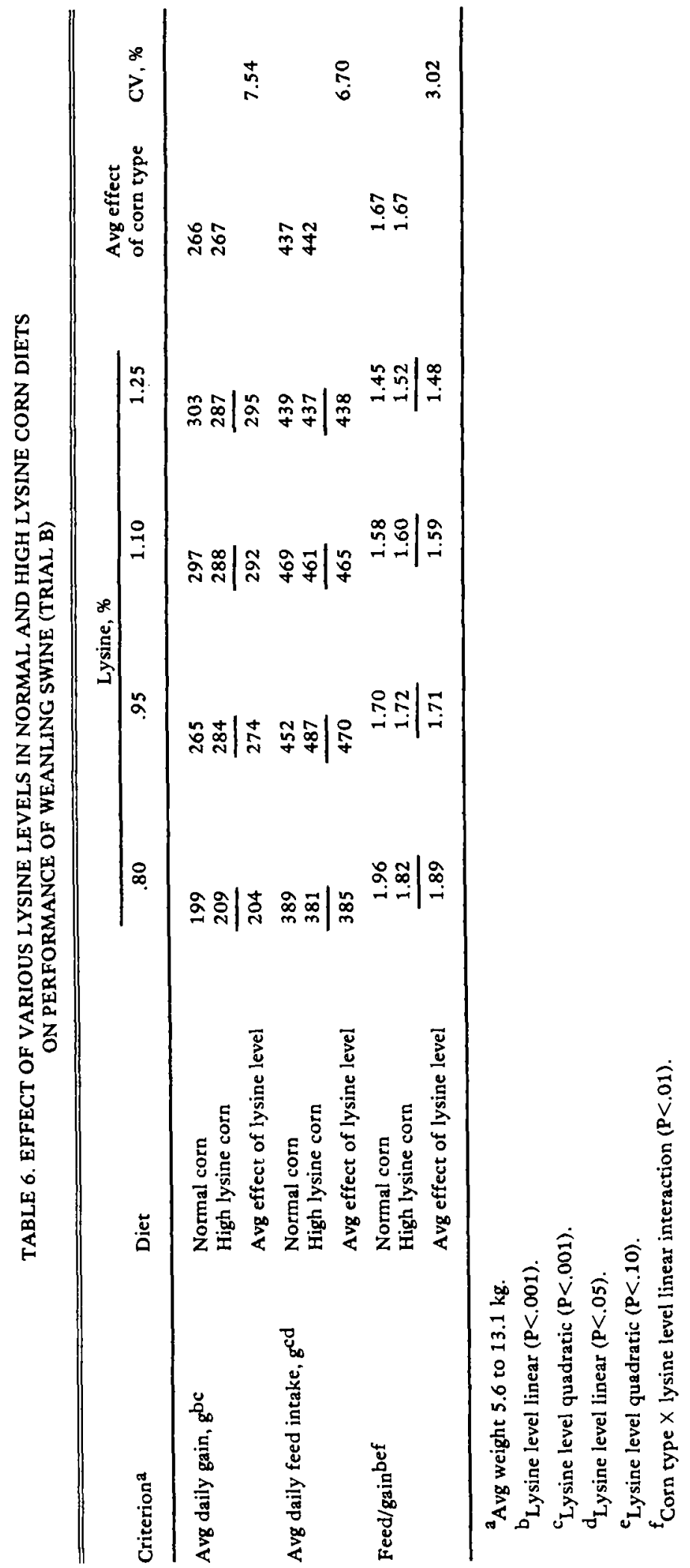


ASCHE ET AL.

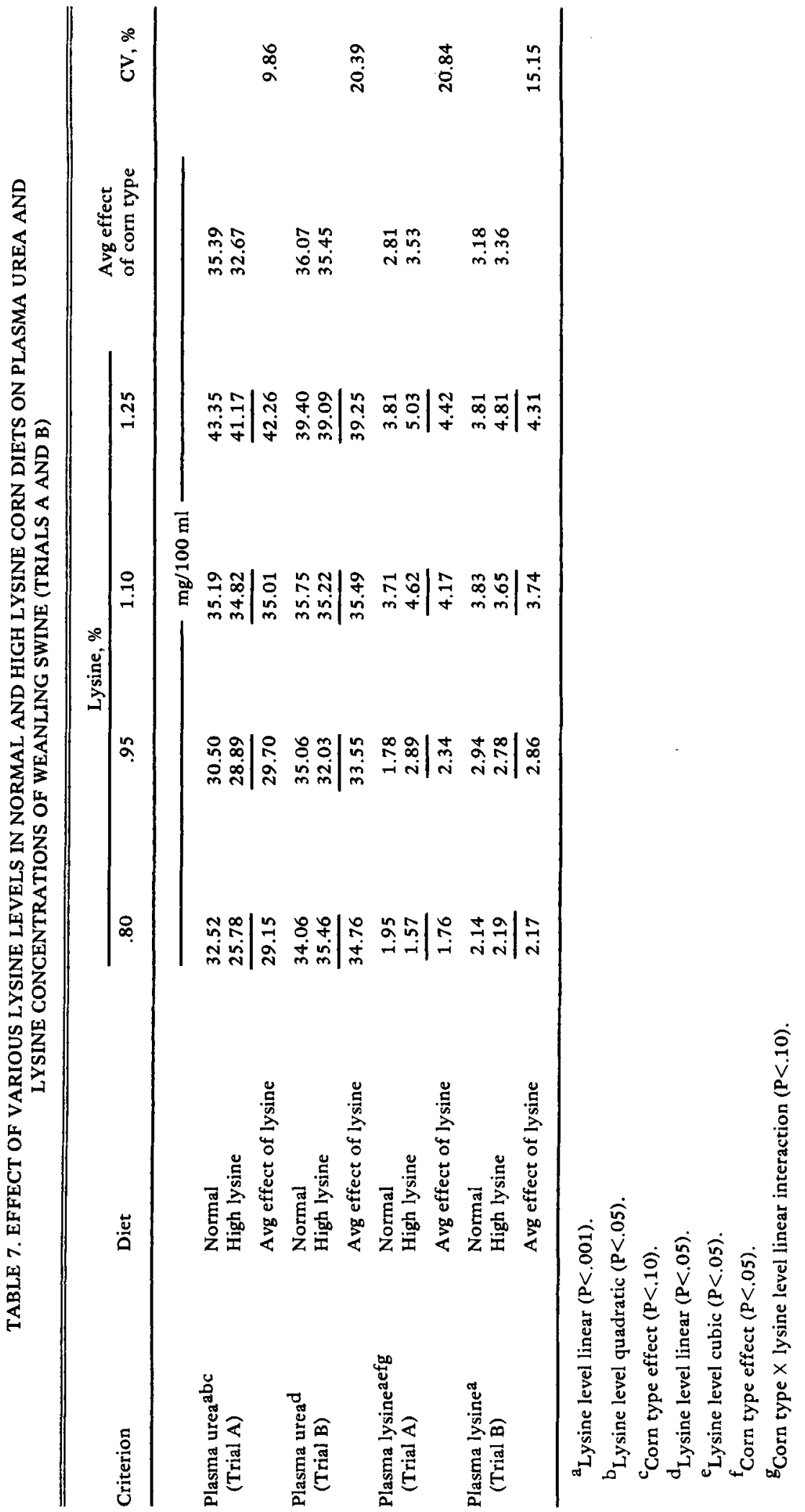




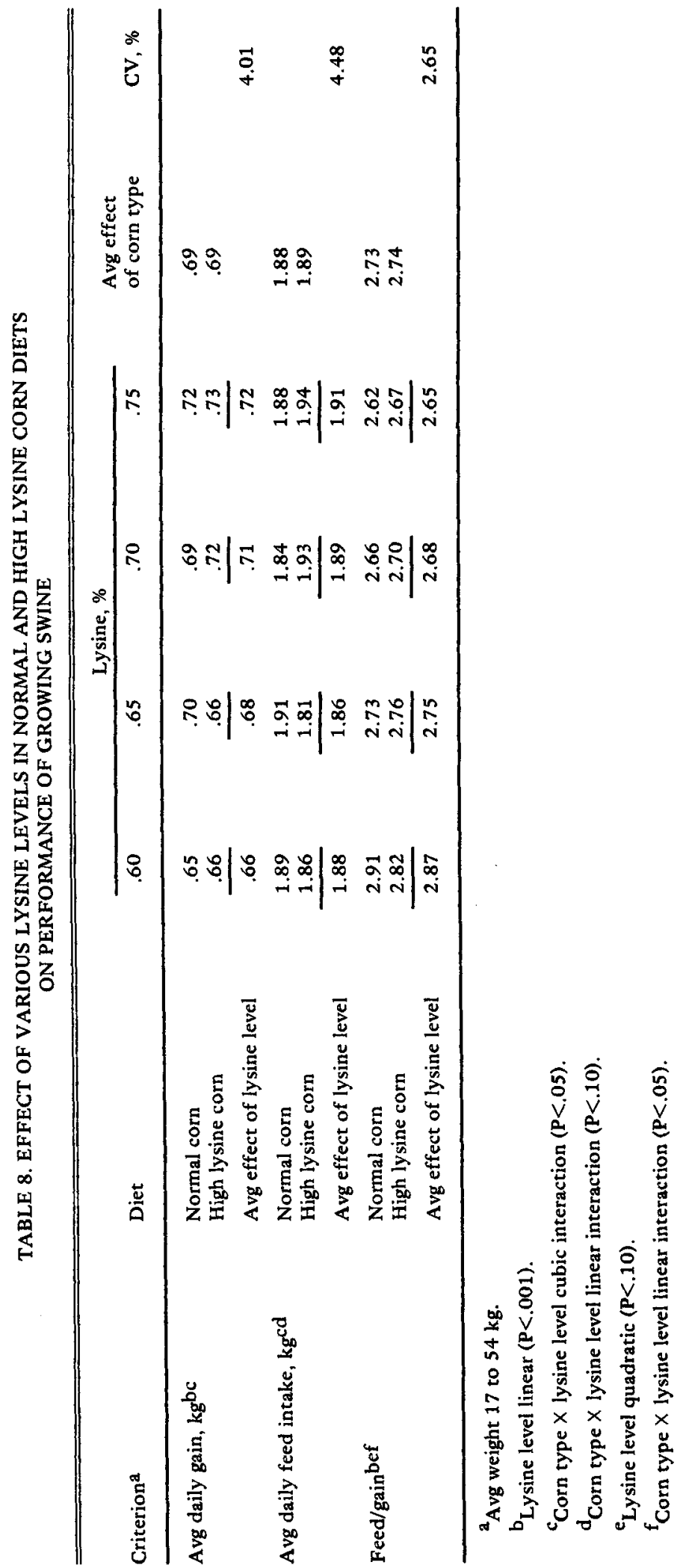


ASCHE ET AL.

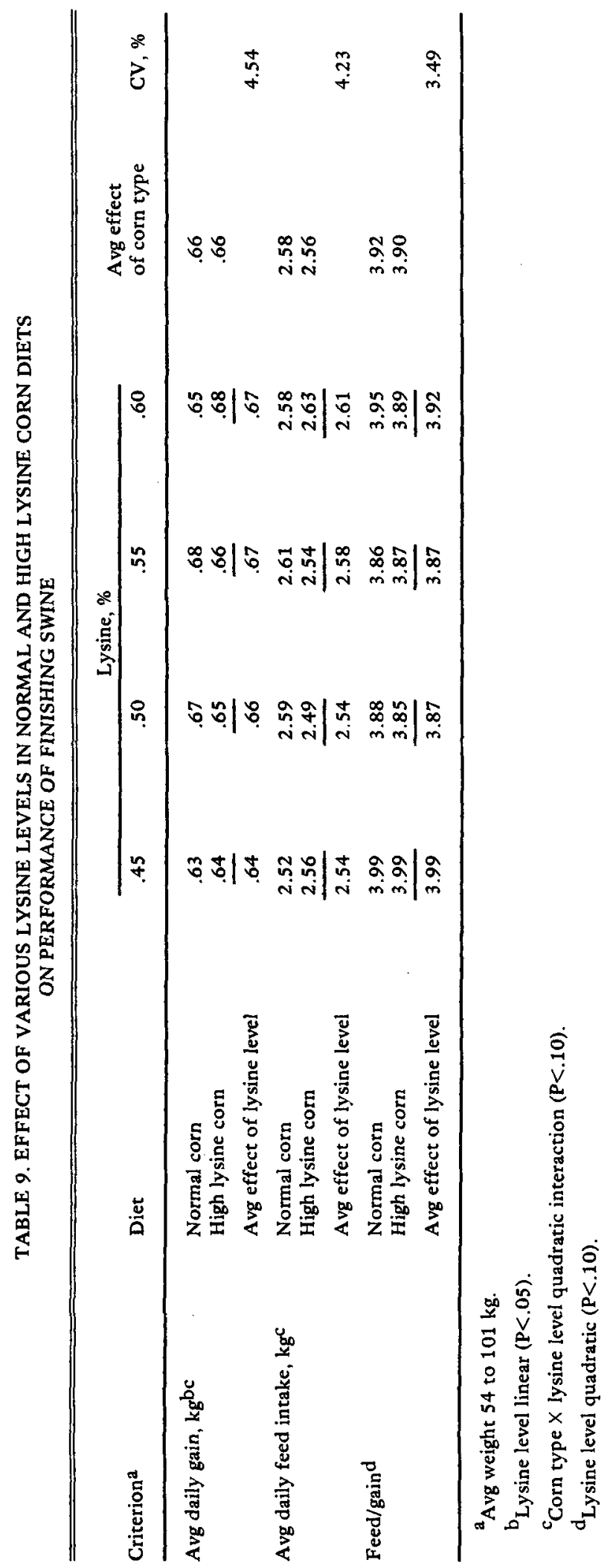




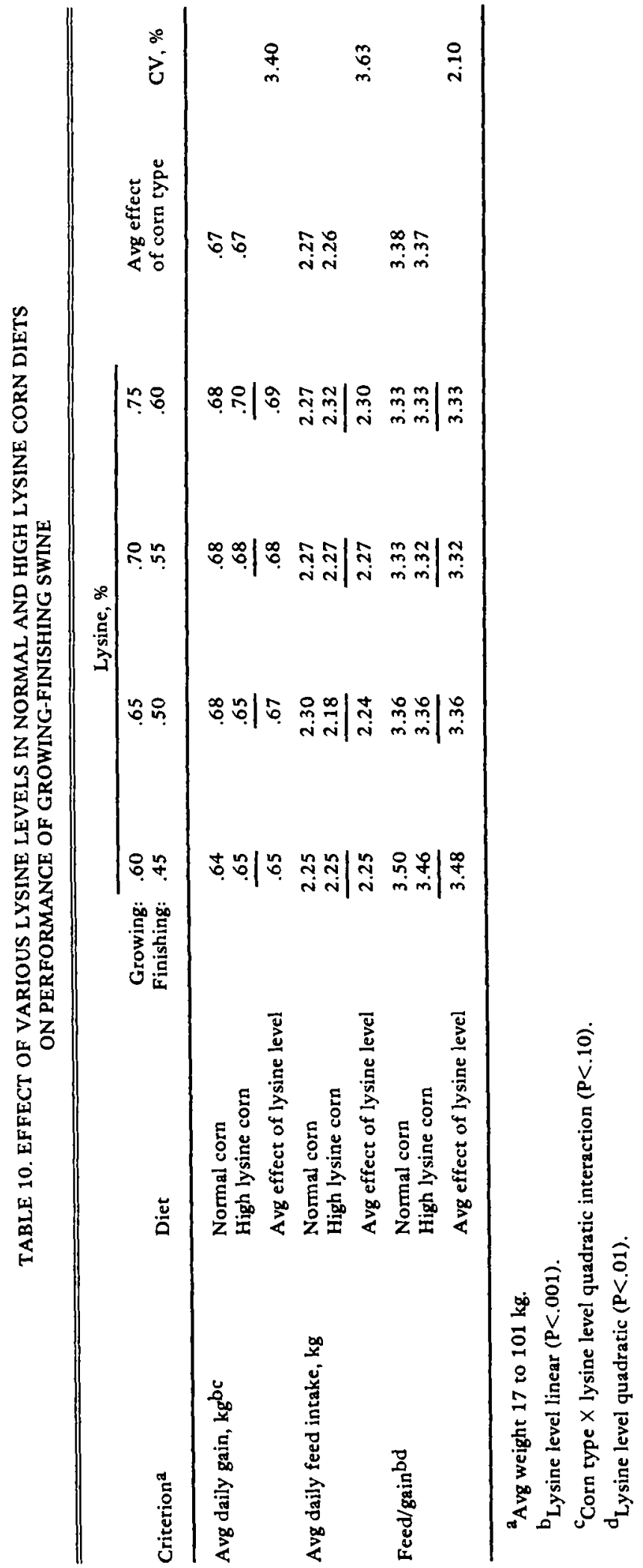


ASCHE ET AL.

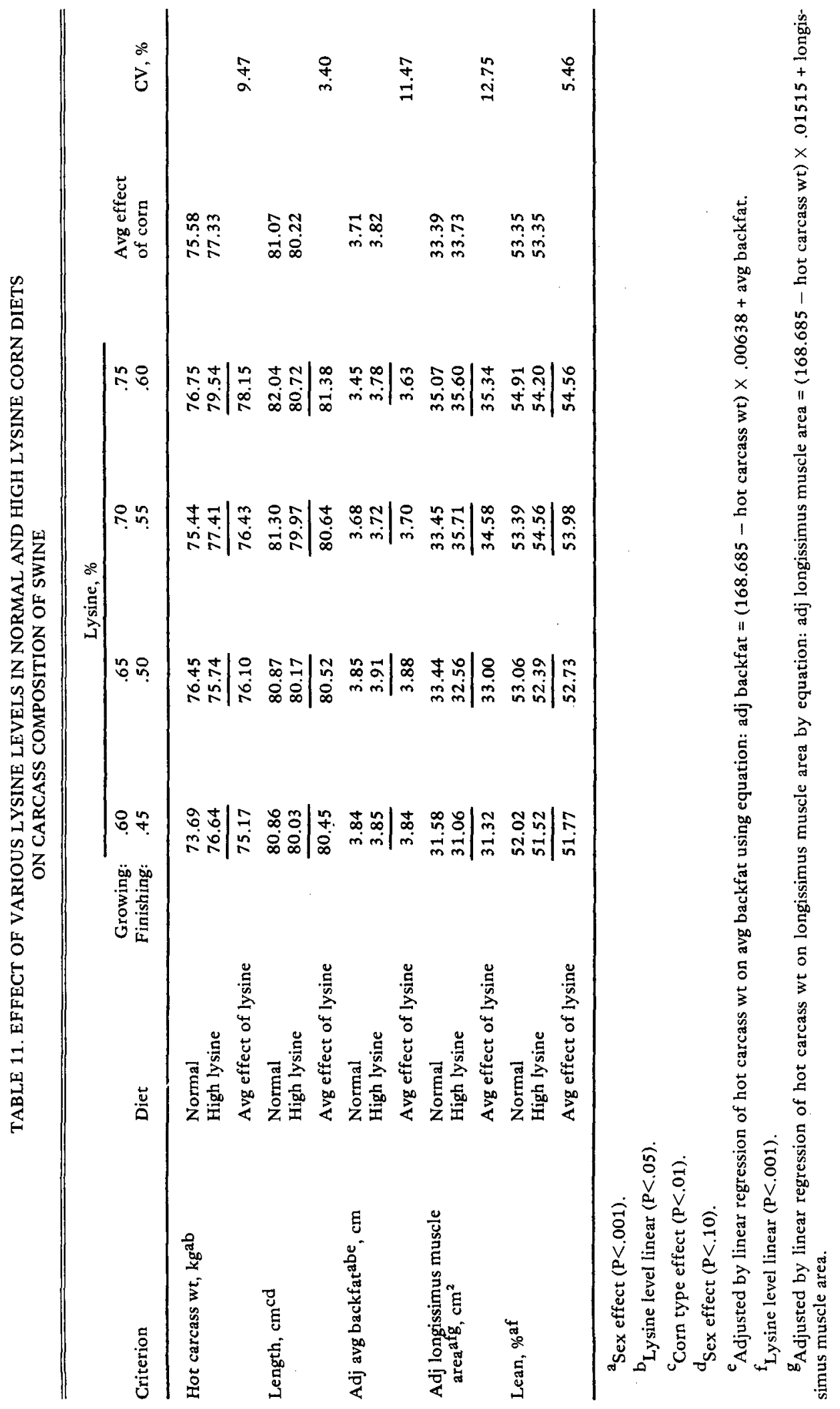


carcass weight, ALMA and percentage lean and decreased AABF thickness. An effect, hard to explain, occurred with carcass length. Pigs fed high lysine corn had slightly shorter (approximately $1 \mathrm{~cm}$ ) carcasses than pigs fed normal corn $(\mathrm{P}<.01)$.

\section{Discussion}

Effect of Corn Type. A consistent finding throughout this research was the lack of a significant main effect for corn type on ADG, ADFI and F/G. Although there was some evidence of corn type $\times$ lysine level interactions, particularly for $F / G$, in general the data demonstrate than when diets are formulated to contain the same lysine levels, inclusion of either normal corn or high lysine corn will result in similar pig performance.

Gipp and Cline (1972), Ekstrom and Mahan (1976) and Mahan (1983) have also found that performance of pigs fed normal and high lysine corn-soybean meal diets was equal when diets were balanced on a lysine basis. In addition, Cromwell et al. (1969) and Gilster and Wahlstrom (1970) reported similar ADG and F/G for pigs fed normal corn and high lysine corn diets with 2 to $4 \%$ less soybean meal than normal corn diets (approximately equal lysine consumption). In contrast, high lysine corn diets have resulted in superior performance when diets were not formulated on an equal lysine basis between corn types (Drews et al., 1969; Sihombing et al., 1969; Marroquin et al., 1973).

Studies of lysine availability using rats (Klein et al., 1972), pigs (Pick and Meade, 1970) or rats and pigs (Rivera et al., 1978a,b) have reported equal or higher lysine availability for high lysine corn than for normal corn.

With the exception of carcass length, corn type did not affect carcass characteristics. The small reduction in carcass length in pigs fed high lysine corn is probably of little biological significance. Cunningham et al. (1973) found shorter carcasses from boars fed a $10 \%$ protein, high lysine corn diet than from boars fed a $14 \%$ protein, normal corn-soybean meal diet, but not with barrows or gilts. The lack of difference between corn types for all other carcass criteria is in agreement with data reported by Veum et al. (1973) and Volz et al. (1975).

Corn type had little effect on plasma urea or lysine concentrations of the pigs in Exp. 1. The only difference $(\mathrm{P}<.05)$ between corn types was that plasma lysine concentrations of pigs in trial A were higher for pigs fed high lysine corn than for pigs fed normal corn. This was despite the fact that the analyzed dietary lysine values tended to be lower in the high lysine corn diets (table 3). In trial $B$, where analyzed lysine values were similar for the two corn types, there was no consistent effect of corn type on plasma lysine concentrations. There were no interactions $(\mathrm{P}<.05)$ between corn type and lysine level on plasma urea or lysine concentrations.

Previous results have been mixed regarding the effect of corn type on plasma metabolites. Neither Veum et al. (1973) nor Volz et al. (1975) found any differences in plasma amino acid concentrations between corn types, when the diets contained amino acid supplements. In contrast, Cromwell et al. (1967) found higher plasma lysine concentrations in pigs fed opaque2 corn than pigs fed normal corn and a nitrogen source.

Effect of Lysine Level. Lysine level affected pig performance in all trials. This was anticipated because the diets were formulated to range from deficient to excessive levels of lysine according to NRC (1979) requirements. In trial A of Exp. 1, weight gain and feed efficiency of pigs fed normal corn were maximized at $1.10 \%$ lysine whereas weight gain and feed efficiency of pigs fed high lysine corn were maximized at $1.25 \%$ lysine, resulting in corn type $x$ lysine interactions. These apparent interactions may have been because the differences between lysine contents based on ingredient analyses and diet analyses were greater for the high lysine corn diets than the normal corn diets (table 3). Results of trial B, Exp. 1 were similar to trial $A$ except that there was less evidence of an interaction and little improvement in weight gain for either corn types when lysine was increased above $1.10 \%$. There was an improvement in $\mathrm{F} / \mathrm{G}$ for both corn types when lysine was increased to $1.25 \%$.

Plasma urea and lysine concentrations were affected by dietary lysine content in both trials $A$ and $B$. The general increase in plasma urea concentration with increasing lysine level probably reflects the increase in protein contents of the diets (table 3 ) and provides little information about lysine requirements. On the other hand, the sharp increases in plasma lysine in both trials between .95 and $1.10 \%$ lysine indicate that the requirement was not met until this point. 
Considered together, the overall data from Exp. 1 (trials A and B) indicate a lysine requirement of approximately $1.10 \%$. This is higher than the current NRC (1979) recommendation (.95\%) but similar to data reported previously by us (Lewis et al., 1980) and by others (Aherne and Nielsen, 1983; Rosell and Zimmerman, 1984).

The data of the growing phase of Exp. 2 (17 to $54 \mathrm{~kg}$ ) indicate a lysine requirement of approximately $.70 \%$. This is similar to the recommendation of the NRC (1979), which lists a requirement of $.70 \%$ for pigs from 20 to $35 \mathrm{~kg}$, and $.61 \%$ from 35 to $60 \mathrm{~kg}$. During the finishing phase $(54$ to $101 \mathrm{~kg}$ ), weight gain and feed efficiency were maximized at approximately $.50 \%$ lysine, which is somewhat lower than the NRC requirement of $.57 \%$ lysine for pigs from 60 to $100 \mathrm{~kg}$. Carcass traits were generally improved up to the highest lysine sequence (.75\% grower; . $60 \%$ finisher). Previous researchers have also reported that carcass traits respond to a higher dietary lysine level than ADG and F/G (Cahilly et al., 1963; Vipperman et al., 1963; Brown et al., $1973 a, b$ ).

Effect of Protein Level on Lysine Requirement. There has been much interest in recent years on the effect of dietary protein level on the lysine requirements of swine. Klay (1964b) reported that the amount of L-lysine $\cdot \mathrm{HCl}$ required for maximum gain, $Y$, of $30-\mathrm{kg}$ pigs increased from .63 to $1.11 \%$ lysine when the dietary protein, $X$, increased from 10.23 to $25.98 \%$ (the regression equation was $Y=$ $.303 \mathrm{X}+.31)$. Schuler et al. (1976) reported that the lysine requirement, $Y$ (dry matter basis), varied as a function of dietary protein, $X$, by the following equation: $\mathrm{Y}=.071 \mathrm{X}-.28$. Easter and Baker (1980) suggested that the lysine requirement can be reduced by $.02 \%$ for each $1 \%$ reduction in dietary protein level when crystalline lysine replaces a portion of the soybean meal in typical diets for growingfinishing swine.

One of the purposes of the present experiment was to examine whether the approximately $2 \%$ reduction in protein levels caused by replacing normal corn by high lysine corn affected the lysine requirement. An approach to answering this question is presented in figure 1. The figure illustrates the relationship between ADG and average lysine intake for each 2-wk interval for both Exp. 1 and 2. Linear and quadratic regressions were fitted through these data for each of the two corn types. The regression lines for each corn type were similar; their slopes were not different $(P>.45)$. The two quadratic regression lines are illustrated in figure 1. It is clear that ADG was dependent on lysine intake, but that at a similar lysine intake ADG was independent of corn type even though there were differences in protein level between corn type (1.5 to $2.0 \%$ less protein in the high lysine corn diets). Apparently in these experiments differences in protein level of up to $2 \%$ did not affect the amount of lysine required by the pigs. A similar relationship between lysine intake (g/d) and ADG was presented by the ARC (1981) in which they summarized the results of 19 experiments with growing pigs (15 to $50 \mathrm{~kg}$ ). The ADG appeared to be dependent on lysine intake and relatively independent of dietary protein level.

In conclusion, in these experiments, diets based on normal or high lysine corn and formulated on an equal-lysine-basis produced essentially the same growth performance in weanling pigs, and the same growth rate and carcass quality in growing-finishing pigs. On the basis of changes in weight gain and feed efficiency, the lysine requirement of weanling pigs was found to be higher, the requirement of growing pigs was similar, and the requirement of finishing pigs was lower than the NRC recommendations. The relationship between dietary protein and lysine level did not appear to be large enough to

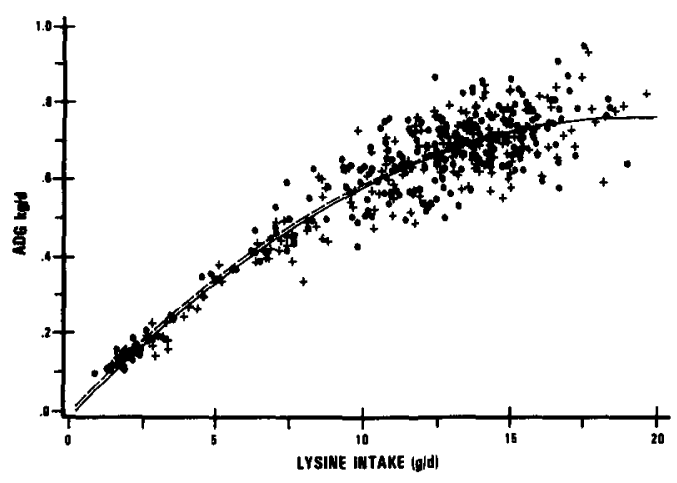

Figure 1. The relationship between lysine intake $(\mathrm{g} / \mathrm{d})$ and average daily gain $(\mathrm{kg} / \mathrm{d})$ of pigs from 5 to $100 \mathrm{~kg}$. Each point represents the value for a pen of pigs (4 pigs weanling; 10 pigs growing-finishing) during a 2-wk period. Pigs fed normal corn are represented by + , and pigs fed high lysine corn by $\bullet$. The quadratic regression equation for the normal corn diets (- - -) was $\mathrm{Y}=-.0134+.0776 \mathrm{X}-.0019 \mathrm{X}^{2}$; the quadratic regression equation for the high lysine corn diets $(\longrightarrow)$ was $Y=-.0091+.0806 X-.0021 X^{2}$. 
cause any significant changes in growth performance or carcass quality. The lysine requirement of weanling and growing-finishing pigs was not affected by a $2 \%$ reduction in dietary protein level.

\section{Literature Cited}

Aherne, F. X. and H. E. Nielsen. 1983. Lysine requirement of pigs weighing 7 to $19 \mathrm{~kg}$ liveweight. Can. J. Anim. Sci. 63:221.

AOAC. 1980. Official Methods of Analysis (13th Ed.). Association of Official Analytical Chemists, Washington, DC.

ARC. 1981. The Nutrient Requirements of Pigs. $p 91$. Commonwealth Agriculture Bureaux, Slough, England.

Baker, D. H., R. S. Katz and R. A. Easter. 1975. Lysine requirement of growing pigs at two levels of dietary protein. J. Anim. Sci. 40:851.

Benson, J. R, and P. E. Hare, 1975. o-Phthaldehyde: Fluorogenic detection of primary amines in the picomole range. Comparison with fluorescamine and ninhydrin. Proc. Natl. Acad. Sci. USA 72:619.

Brown, W. L. 1975. Worldwide seed industry experience with opaque- 2 maize. In: E. T. Mertz (Ed.) High Quality Protein Maize. pp 256-264. Dowden, Hutchinson and Ross, Inc., Stroudsburg, PA.

Brown, H. W., B. G. Harmon and A. H. Jensen. 1973 a. Lysine requirement of the finishing pig for maximum rate of gain and efficiency. J. Anim. Sci. 37:708.

Brown, H. W., B. G. Harmon and A. H. Jensen. 1973b. Lysine requirement of the finishing pig for maximum carcass leanness. J. Anim. Sci. 37:1159.

Cahilly, G. M., Jr., R. F. Miller, R. F. Kelly and C. C. Brooks. 1963. Effect of various levels of dietary lysine on certain blood phenomena, muscle development and muscle protein biological value for growing swine. J. Anim. Sci. 22:726.

Cromwell, G. L., R. A Pickett and W. M. Beeson. 1967. Nutritional value of opaque-2 corn for swine, J. Anim. Sci. 26:1325.

Cromwell, G. L., R. A. Pickett, T. R. Cline and W. M. Beeson. 1969. Nitrogen balance and growth studies of pigs fed opaque-2 and normal corn. J. Anim. Sci. 28:478.

Cunningham, P. J., T. E. Socha, E. R. Peo, Jr. and R. W. Mandigo. 1973. Gain, feed conversion and carcass traits of swine fed under two nutritional regimes. J. Anim. Sci. 37:75.

Drews, J. E., N. W. Moody, V. W. Hays, V. C. Speer and R. C. Ewan. 1969. Nutritional value of opaque-2 corn for young chicks and pigs. J. Nutr. 97:537.

Easter, R. A. and D. H. Baker. 1980. Lysine and protein levels in corn-soybean meal diets for growing-finishing swine. J. Anim. Sci. 50:467.

Ekstrom, K. E. and D. C. Mahan, 1976. Feedlot comparison of regular, high-lysine (opaque-2) and waxy corn for growing-finishing swine fed either as a complete mix or free choice. Ohio Swine Day Rep., Ohio Agr. Res. and Development Center, Wooster, OH. p 56.
Fahey, T. J., D. M. Schaefer, R. C. Kauffman, R. J Epley, P. F. Gould, J. R. Romans, G. C. Smith and D. G. Topel. 1977. A comparison of practical methods to estimate pork carcass composition. J. Anim. Sci. 44:8.

Gallo, J. T., M. Corzo and J. H. Maner. 1968. Value of opaque-2 corn for finishing pigs. J. Anim. Sci. 27:1152 (Abstr.).

Gilster, K. E. and R. C. Wahlstrom. 1970. High lysine corn in growing-finishing swine rations. Swine Day. South Dakota State Univ. AS Series 70-41: 46.

Gipp, W. F. and T. R. Cline. 1972. Nutritional studies with opaque-2 and high protein opaque-2 corns. J. Anim. Sci, 34:963.

Jensen, A. H., D. H. Baker, D. E. Becker and B. G. Harmon. 1969. Comparison of opaque-2 corn, milo and wheat in diets for finishing swine. $J$. Anim: Sci. 29:16.

Klay, R. F. 1964a. Lysine and nitrogen utilization by pigs at four protein levels. J. Anim. Sci. 23:881 (Abstr.).

Klay, R. F. 1964b. The lysine requirement for growth of the pig at four protein levels. J. Anim. Sci. 23:881 (Abstr.)

Klein, R. G., W. M. Beeson, T. R. Cline and E. T. Mertz. 1972. Lysine availability of opaque-2 corn for rats. J. Anim. Sci. 35:551.

Lewis, A. J., P. J. Holden, R. C. Ewan and D. R. Zimmerman. 1976. An automated fluorometric method for the messurement of tryptophan in plasma. Agr. Food Chem. 24:1081.

Lewis, A. J., E. R. Peo, Jr., B. D. Moser and T. D. Crenshaw. 1980. Lysine requirement of pigs weighing 5 to $15 \mathrm{~kg}$ fed practical diets with and without added fat. J. Anim. Sci. 51:361.

Lunchick, C., A. J. Clawson, W. D. Armstrong and A. C. Linnerud. 1978. Protein level, lysine level and source interaction in young pigs. J. Anim. Sci. $47: 176$

Mahan, D. C. 1983. High lysine corn for growingfinishing swine - A current evaluation. Ohio Swine Res, and Ind. Rep., Ohio State Univ., Wooster, OH. p 22.

Marroquin, C. R., G. L. Cromwell and V. W. Hays. 1973. Nutritive value of several varieties of opaque-2 corn and normal corn for growing swine. J. Anim. Sci. 36:253.

Marsh, W. H., B. Fingerhut and H. Miller. 1965. Automated and manual direct methods for the determination of blood urea. Clin. Chem. 11:624.

Mertz, E. T., L. S. Bates and O. E. Nelson. 1964. Mutant gene that changes protein composition of maize endosperm. Science 145:279.

Mondino, A., G. Bongiovanni, S. Fumero and L. Rossi. 1972. An improved method of plasma deproteination with sulfosalicylic acid for determining amino acids and related compounds. J. Chromat. $74: 255$.

Nelson, O. E. 1966. Mutant genes that change the composition of maize endosperm proteins. Fed Proc, 25: 1676.

Nelson, O. E., E. T. Mertz and L. S. Bates. 1965. Second mutant gene affecting the amino acid pattern of maize endosperm proteins. Science 150: 1469 .

NRC. 1979. Nutrient Requirements of Domestic 
Animals, No. 2. Nutrient Requirements of Swine. Eighth Revised Ed. National Academy of Sciences - National Research Council. Washington, DC.

Pick, R. I. and R. J. Meade. 1970. Nutritive value of high lysine corn: Deficiencies and availabilities of lysine and isoleucine for growing swine. J. Anim. Sci. 31:509.

Pickett, R. A. 1966. Opaque-2 corn in swine nutrition. Proc. High-Lysine Corn Conf. pp 19-22. Corn Ind. Res. Found., Inc., Washington, DC.

Rivera-L., P. H., E. R. Peo, Jr., D. Flowerday, T. D. Crenshaw, B. D. Moser and P. J. Cunningham. 1978a. Effect of maturity and drying temperature on nutritional quality and amino acid availability of normal and opaque-2 corn for rats and swine. J. Anim. Sci. 46:1024.

Rivera-L., P. H., E. R. Peo, Jr., D. Flowerday, T. D. Crenshaw, B. D. Moser and P. J. Cunningham. 1978b. Effect of drying temperature on nutritional quality and availability of amino acids in normal and opaque-2 corn for rats. J. Anim. Sci. 46:1275.

Rosell, V. L. and D. R. Zimmerman. 1984. Effects of graded levels of lysine and excess arginine and threonine on young pigs fed practical diets. J. Anim. Sci. 59: 135 .

SAS. 1979. SAS User's Guide. Statistical Analysis
System Institute, Inc., Cary, NC.

Schuler, D., K. H. Bodenstein and A. Henning. 1976. Determination of the lysine requirement of the growing pig as a function of the protein level. Arch. Tierernahrung 26, H 9, S. 643.

Sihombing, D.T.H., G. L. Cromwell and V. W. Hays. 1969. Nutritive value and digestibility of opaque2 and normal corn for growing pigs. J. Anim. Sci. 29:921.

Steel, R.G.D. and J. H. Torrie. 1980. Principles and Procedures of Statistics (2nd Ed.). McGraw-Hill Book Co., New York.

Veum, T. L., W. H. Pfander, C. G. Bellamy and H. B. Hedrick. 1973. Opaque-2 and normal corn as amino acid sources for barrows and gilts. $J$. Anim. Sci. 36:877.

Vipperman, P. E., Jr., C. C. Brooks, R. F. Kelly, P. P. Graham and H. R. Thomas. 1963. Effect of dietary lysine level on muscle size and composition in swine. J. Anim. Sci. 22:674.

Volz, J. G., R. C. Wahlstrom and G. W. Libal. 1975. Lysine and tryptophan additions to opaque- 2 and normal corn. J. Anim. Sci. 41:330 (Abstr.).

Wahlstrom, R. C., R. V. Merrill, L. J. Reiner and G. W. Libal. 1977. Mutant corns in young pig diets and amino acid supplementation of opaque- 2 corn. J. Anim. Sci. 45:747. 